\title{
THE FIFTH GLOBAL KONDRATIEV. LOW ECONOMIC PERFORMANCE, INSTABILITY AND MONOPOLIZATION IN THE DIGITAL AGE
}

The capitalist expansion based on ICTs configured could be considered an ascending Kondratiev wave, understood since the beginning of the 1980s to the outbreak of the financial crisis in 2008. This expansive wave has had its dynamic centre in the United States capitalism, originator and leader of digital and network technology. This Kondratiev has limitations of amplitude and rhythm that have resulted in a premature decline in the productivity performance. The weakness of the fitth Kondratiev is not due to a problem of technological exhaustion but to a precarious socio-political and institutional support in the hegemonic country. This means that the US digital monopolies supported by the peculiar institutionality of that country concentrate the economic benefits, causing general effects of exclusion and social marginalization. The only United States competitor is the People's Republic of China, which has managed and created a successful digital economy, which in the span of a decade could contest the hegemony of the leading country. This competitive struggle, which is not only commercial but politico-institutional, will determine if the fifth Kondratiev, now in a phase of economic depression, experiences a rebound, mutates in another Kondratiev based on artificial intelligence or opens a prolonged period of uncertainty and instability global accentuated. The deregulation and the absence of counterweights characteristic of United States institutions explain the conversion of powerful digital technology into a disruptive factor instead of an integrating factor. The other world powers, with the exception of the People's Republic of China, have become just users of digital products and services generated by the United States. Only the People's Republic of China has ventured, and successfully, to become a digital producer, competing directly with American monopolies. But to the extent that this competition is not primarily about trade and market in the conventional sense, but a clash of normative models of social exploitation of the digitalization, we are properly before a struggle for world hegemony.

Keywords: investing, venture capital, gross domestic product, profits, productivity, digitization index.

Introduction. The low economic performance of recent decades, especially productivity in developed countries, as in the United States, has caused a mixture of perplexity, consternation and interest among experts and policymakers, especially because we still live in a time of portents of the technology. Robert Gordon in his book "The Rise and Fall of American Growth" (2016) sized, in a broad historical perspective, the relationship between technology, productivity and economic growth in the main world power, i.e., the United States. Gordon argues that fingering and networks, that is, the axis of the current technological paradigm, constitute a system of limited depth, especially in comparison to the technology of the second 
industrial revolution (electric motor and mass production-consumption). The limited technological depth of the current paradigm, says Gordon, added to adverse changes in the social structure (low in the demographic rate) has had a negative impact on the performance of productivity, which in its best period, 1994-2004, represented only 60\% of the rate achieved from 1920 to 1970 (Gordon, op. cit., graph 17.2).

The financial crisis arose when the pace of productivity came down; then came the great global recession and the prolonged period of low global growth that still persists. As noted, the problem has grown in complexity so it may be asked: Have the secular forces that drive world growth weakened as a result of something close to "technological exhaustion or normalization" or is it a serious but cyclical disaster and therefore surmountable in the long run? The multilateral organizations, mainly the IMF, are optimistic, arguing that the recovery of the current recessive situation has been verified, albeit at a slow pace. By contrast, for other authors such as Michael Roberts (2016) the indicators of low economic performance correspond to an economic depression, that is, a fall deeper than the recession and with a tendency to perpetuate itself, but also in the long run surmountable. A group of Keynesians, among them Larry Summers (2014), argue that this would be a persistent gap between potential growth and real growth in the world's leading economies, whose main cause is "demand deficiency", specifically, excess of savings (in the same sense pronounced Dumas, 2010 and Krugman, 2012).

Trying to organize the debate, two vectors are noticed: a) Are we facing a severe but transitory phenomenon (i.e. cyclical) in the process of overcoming or is it an emerging trend of low performance that will persist indefinitely? b) Is the main cause of low or declining performance is the technological or nontechnological origin? If the cause is mainly technological, the reasoning would basically be that described by Gordon (op cit.). In a non-technological explanation, it can be assumed that the productive forces of capitalism have been strengthened, but their regular functioning is obstructed by cyclical contradictions.

Without dismissing the discussion about the determining forces of long-term economic growth, the attention should be focused on the background of the debate. What is debated in the background is whether, after having been so profoundly transformed in the last forty years, capitalism will be able to preserve its integrity, that is, preserve the articulation between its system of power and its control of social wealth? This articulation could be subjected to a strong tension if the definitive leap towards artificial intelligence occurs.

Many of the arguments presented in the debate are relevant but are insufficiently integrated into a historical vision of the great stages or eras of global expansion. Such vision would have to be articulated around the theory of long waves Kondratiev type. Unfortunately, this macro-approach, despite its enormous potential, overcomes several methodological questions and factual grounds, which have undermined its scientific acceptability. However, a critical review of the main authorial contributions indicates that it is possible to arrive at a modified notion of the long waves of capitalist development, which overcomes the commonly formulated questions. The objective of this article is to formulate a tentative proposal of this theoretical framework to apply it to the problems described above. It is a first proposal with the intention of participating in this crucial debate, without pretending to offer a definitive interpretation.

The hypothesis formulated is the following one: the capitalist expansion sustained in the ICTs configured what can be considered an ascending Kondratiev wave. This expansive wave has its dynamic centre in American capitalism, originator and leader of digital technology and networks. This fifth Kondratiev (VK) has limitations of amplitude and rhythm that have resulted in the referred premature decline in productivity performance. However, we are not facing a technological flattening, because digital and network technology has considerable current and potential strength. The weakness of the VK is due to another cause: the precarious socio-political and institutional support provided by neoliberalism to the current technological paradigm in the leading country and hegemonic power. Although US technology corporations take the majority share of global profits, paradoxically they have contributed to causing a "digital disruption" due to institutional gaps, which has translated into the problems of low economic 
performance referred to above. This means that the enormous economic gains derived from this technological system are highly concentrated in a nucleus with monopoly power, causing general effects of exclusion and marginalization that extend beyond the economic space of that country.

The stage of low growth that is currently lived could play the same role as the depression of the 1930s in relation to the fourth Kondratiev (IVK), that is, at the same time it expresses the precarious social modulation of the current techno-productive system (before the electric motor together with the assembly line and now the digitalization), tend to induce a reform in the socio-institutional system to match technology to social requirements. However, in the current period the long wave dynamics seem to intertwine with the culmination of the hegemonic cycle, in other words, in the VK the American hegemony would be, from the beginning of the 1970s, in its phase of "delegitimization" or "deconcentration" (see Modeski, 1987; Modeski and Thompson, 1996; Goldstein, 1988), which implies, at the same time, the emergence of a serious contender.

Technological disruption in the US coincides with the rise and challenge of a new global power: the People's Republic of China (PRC), which, enjoying the advantages of followers has advanced considerably in the assimilation of digital and network technology, integrating it into an alternative socioinstitutional system, which expands its social cohesion, translating into greater competitive capabilities on a global scale. The foregoing would mean that the dynamics of the VK (or the possible emergence of a sixth) will be determined by the course followed by the hegemonic cycle, that is, the change in the global power structure.

The objective of this article is to clarify the peculiar shortened profile of the VK and the relationship with the technological system of digitalization-networks and the role played by the current neoliberal socioinstitutional framework. In function of that objective, the exposition is ordered as follows: in the first section an alternative theoretical framework scheme is formulated on the long waves, which although endorses the notion of endogenous causation, differs in a central aspect of the "standard model" derived of the original works of Kondratiev: the one that refers to the waves of regular duration. As an alternative and following the theorization of SPRU-Sussex (Freeman and Pérez, 1988), it is adopted: a) the concept of mixed waves of long duration, that is to say, that the installation of a new technological paradigm coincides with the terminal maturation of the previous one and $b$ ) that economic growth fundamental determinant is not merely technology, but the socio-political and institutional "molding" of that technology (which is expressed in the so-called socio-institutional framework). However, unlike the approach of SPRU-Sussex, and following Tylecote (1992), it is considered that the relationship between technology and society tends to be irregular, which implies decoupling of different intensity, which invalidates the wave rule of duration pre-determined and regular.

In the second section, some of the distinctive aspects of digitalization as a generic technology are analyzed, following the concept formulated by several authors, including Carlsson (2004) to implicitly refute the argument of technological "flattening" sustained mainly by Gordon (op cit.). In particular, the attention is focused on the historical modality adopted by the new paradigm in the United States from the convergence between "information" (computing) and "communication" (internet). In a third section we compare the digital disruption experienced by the leading power with the incipient conversion of China into the rival digital power of the USA, a process that, as noted, can have a decisive influence on the hegemonic cycle. The conclusions unify the expositions set out in the three sections, trying to formulate what seems to be the perspective or most likely scenario in relation to the dynamics of the VK or the possible transition to a sixth Kondratiev (VIK).

Theoretical Framework. Capitalism has a very strong propensity for growth and to expand the limits of its productive capacity continually (Marx, 1946, volume III, third section, chapter XV). Historically it has been demonstrated that this expansive force is exerted discontinuously, resulting in recurrent phases of expansion and contraction of economic activity. 
Since the beginning of the twentieth century, but especially in the 1930s, some scholars of what we would call today growth theory came to the conclusion that there seemed to be a more fundamental form of expansion and contraction than that identified with the "short" cycles (Kitchin and Juglar). Jevons long before (cited by Tylectoe, 1992) had had what can be called a first intuition to observe shock waves and long-term contraction in the general level of prices, from 1790 to 1849 in the United Kingdom. Under the influence of Jevons, the dutch Van Gelderen (1996) calculated a second expansive and contractive long wave of prices from 1850 to 1896.

Nicolai Kondratiev's studies carried out in the 1920s laid the foundations for the predominant approach of long waves. Although the data used by the Russian author were predominantly price series (1979 [1925]), he extended the reasoning to production, delimiting the joint duration of a long wave to a period of 45 to 60 years, in accordance with the first empirical observations (2008 [1928]). For this author, the motor of the shock wave is the investment in capital basic goods (op. cit.). With these two specifications Kondratiev and his followers answered the two fundamental methodological questions: Are the long waves of a regular duration? Is there a single and clearly determined motor force? In both cases the answer was affirmative.

As pointed out by Solomou (1988), the historical data from the beginning of the 20th century refuted the idea of waves of regular duration, which put into question the hypothesis expounded by Kondratiev, confining in the long run the study of long waves to rather restricted groups of researchers. There was another reason for controversy. Assuming that capitalist expansion is discontinuous, that is, progressing in regular ascending and descending waves, Kondratiev made explicit with exceptional force a decisive observation for the following decades. No matter how severe a crisis and the recession or depression in which capitalism was, the very logic of the process of capital accumulation would lead to a later recovery, guaranteeing durability to the capitalist system. The previous statement was, especially in the context of the depression of the 1930s, a forceful takeover of the position in the confrontation capitalism vs. communism in the interwar period.

The controversy between Kondratiev and Trotsky was around the notion of durability and epochal stability of capitalism and was expressed in the contrast between endogenous and exogenous causation of wave motions. For Marxism, as Trostky (1979, op. cit.) put it, there was only the vision of a capitalism that inexorably advanced to its self-destruction, and the undulations necessarily obeyed exogenous factors, such as wars and discoveries of gold and other shocking events.

Long waves and worldviews. As Goldstein (1988) rightly points out, the aforementioned discussion should not be seen in itself, but as a broader confrontation of worldviews. On the one hand, there is a liberal vision that "... focuses on the evolution of the existing order ... [and] the continuous progress generated by innovation (op. cit.)". On the other hand, he adds, there is the revolutionary approach that adopts the perspective of the inevitable destruction of the existing order by its own contradictions that induce it to frequent crises and, consequently, to its denial and transformation.

It is difficult to place Kondratiev as a liberal or revolutionary, because besides being a pioneer he had attributes of both visions; what is clear, however, is that Joseph Schumpeter (2012), being a determined liberal, aligned the theoretical legacy of Kondratiev in that perspective. The Marxists represent the axis of the revolutionary vision, but they have great difficulties to reconcile the postulate on the descending tendency of the rate of profit of Marx with the long waves.

This confrontation of world's visions were expressed in the formulation of hypotheses and theories of long waves since the 1920s, but with limited communication between both visions, because they are antagonistic. A synthesis that allows applying a long wave approach to global change, specifically the passage from VK to VIK requires taking elements located in both visions.

With Schumpeter's work (op. cit.) the liberal view of long waves acquired its greater theoretical stature, leading later to successive tunings and additions. The cornerstone of this author's theorizing was that the 
driving factor is technological innovation, understood as any change that is generated in the methods of production of goods, including, in addition to technological change in the strict sense, the opening of new markets, new organizations and methods of work (op. cit.). According to him, the long wave derives from major innovations, creators of a leading industrial sector, which expands for a long time until reaching its diminishing returns, initiating an equivalent decline in its duration; this necessary decline will inevitably be transformed into a new long-term rise (lbid.).

But Schumpeter leaves a question unanswered, in addition to establishing a direct relationship between technology and capitalist dynamics of the liberal vision that is problematic. The question is: if what trigger an expansive wave are innovations in clusters, how is their recurrent appearance explained every fifty-odd years? This question expresses the background of skepticism that surrounds the theorization of long waves as Solomou (op. cit.), Kuznets (1996) and later Rosenberg \& Frischtak (1996) insisted.

The more general problem of the liberal vision is, as it is noticed, its belief that there is harmony and synchronization in the dynamics of the long wave. In this perspective, Schumpeter's disciples undertook the task of refining the concepts to try to make that harmony and synchrony scientifically credible. This leads us to Mensch (1979), Freeman \& Pérez (1988), but with unequal contributions. The controversy between Mensch (op. cit.) and Freeman \& Pérez (op. cit.) leads to the crucial concept of technological systems as an articulated and hierarchical set of innovations. Despite the importance of the concept of technological systems, the question remains: is there continuity from one technological system to another? And is such continuity a structural feature of capitalism?

There is an answer to these questions, but it was not formulated within the framework of the theorization of long waves. The essence of these questions is due to Simon Kuznets (1973), author who had formulated an early critique of Schumpeter's approach. Kuznets (op. cit.) formulated the theory of continuous innovation supported by organizational and institutional changes that first appeared in Germany at the end of the 19th century and then passed and deepened in the USA from the beginning of the 20th century (Ibid.). The continuity of technological change was an observable phenomenon around $1920-1930$, so that Schumpeter's theorization tried to give it a theoretical basis associated with the tendency of capitalism to expand discontinuously.

The insufficiency of Neo-Schumpeterian technological paradigm was evidenced by the emergence of Ernest Mandel (1986) in the debate. Mandel wrote under the influence of the world instability of the 1970s, what is generally understood as a descending Kondratiev. As will be remembered, Marxism almost officially broke with the theory of long waves after the Kondratiev-Trostky debate. Mandel argued that this refusal closed the door to the Marxists to an important field of reflection and debate. Unfortunately, the response of the aforementioned author was limited.

The argument that synthesized the revolutionary vision of long waves, as Mandel argued, is that there is a close relationship between long waves and class struggle. The expansive wave means, stressed Mandel, greater power for wage-earners, because it empties the reserve industrial army and this contributes to raise wages, compressing profits; in turn, the recessive wave leads eventually to the defeat of workers due to the obvious effect of unemployment and depreciation of wages.

Unfortunately, Mandel's formulation was at best insufficient, because the link between wages and earnings is part of a broader socio-political and institutional problem and tends to present reflex qualities, that is, it is induced by other forces. Furthermore, the idea that the proletariat will necessarily be defeated every 40-60 years is the inverse of the liberal vision.

The merit of Mandel in any case lies in having pointed out the inadequacy of Schumpeter's theorization regarding the direct relationship between technology and economic growth. It is in the aforementioned context that the contribution of Freeman \& Pérez of the late 1980s acquires relevance. The great step taken by both authors is to formulate an analytical scheme that disaggregates the sequence of the 
transformation process detonated by the first arrival (or installation) of a new technological system or techno-economic paradigm (TEP). The first impact of the installation of a new technological revolution is, so to speak, cultural and lies in the emergence of a "new common sense"; in other words, with the new technological resources a mental and behavioural change is promoted, but limited to the specialist strata. However, in order for the technological revolution to spread, it is necessary to solve socially, politically and institutionally the dilemma presented by technological change (second impact). This dilemma is expressed in an attempt to achieve a certain balance between winners and losers as a result of "creative destruction", but also to create institutions that promote social interaction in accordance with technological change. This social use of technology would at the same time be an ideal means to maximize their socio-economic returns.

Both impacts not only oppose capitalists and wage-earners, but capitalists against capitalists and wage-earners versus wage-earners. Freeman \& Perez (1988) argue that the technological system induces a socio-political solution that is "institutionalized" and facilitates the necessary diffusion of the new technological system and its common sense, within a framework of social stability, that is, of harmony not only of class but intra-classist. The referred attempt of solution is the call system or socio-institutional frame (SIF). It is at this point that Tylecote (op. cit.) proposes a reconsideration that rescues the contributions of Freeman \& Pérez, but strips it of its sense of almost perfect harmony (the decouplingcoupling between the paradigm and the socio-institutional framework).

Freeman \& Pérez redesigned: irregular mixed waves. Freeman \& Pérez's model (op. cit.) of every 50 years, is shown in Figure 1 (as a cycle because it is horizontal). It is noticed that there is an economic crisis (caused by the decoupling) in the middle of the wave that resolves with the coupling between the TEP and the SIF. The other crucial aspect is that two TEP coexist, the one that is extinguished, identified as "X", and the new one that is installed, located as "Y". A crucial difference is seen in this approach with the treatment derived from Kondratiev and taken up by Mandel.

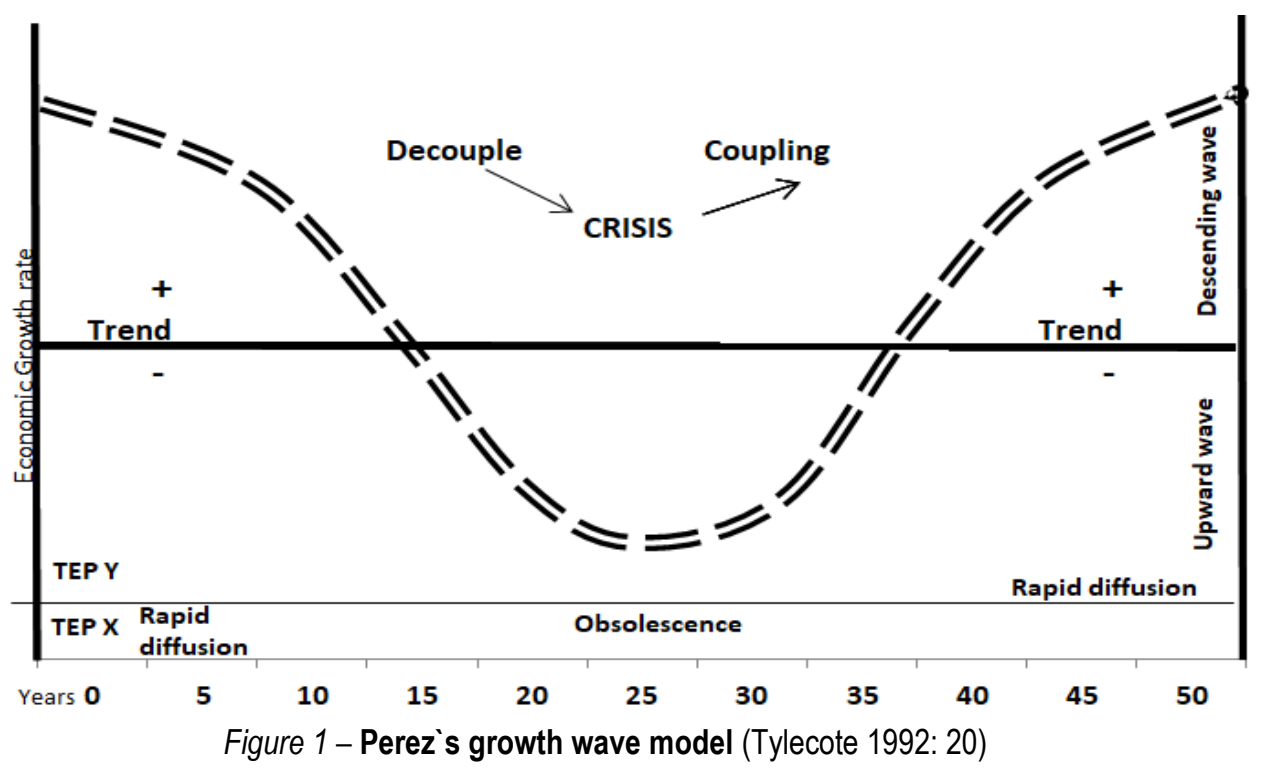

The mixed nature of the long wave and the intermediate "pothole" constitute two crucial questions to understand capitalist dynamics; we will concentrate on the "pothole" or decoupling-coupling crisis to later 
address some aspects of the mixed wave.

The criticism of Tylecote is basically to point out that if there is an uncoupling this can cause not a single type of crisis, but two main ones:

a. The current SIF blocks the dissemination of the new paradigm; this causes an economic crisis, particularly a decline in economic activity, which will lead to a socio-political crisis. The conjunction of economic and socio-political problems implies a "depression" and its example is the 30 s.

b. There is no initial block, while there was some previous reform of the SIF; this allows diffusion and growth. In the long run, there will be, however, increasing political and social pressure derived from the insufficient adequacy of the SIF. Tylecote speaks in this case of a socio-political crisis with certain subsequent economic implications; it's called a growth crisis.

We have arrived, following Tylecote's critique, to the fundamental notion of irregular growth patterns, because scenario "a)" confers on the ascending/descending wave a different duration from scenario "b)". The economic depression postpones the next subphase of the shock wave, while the growth crisis shortens the shock wave. This notion clears the ground because it solves the problem observed by Solomou (1988).

In Figure 2 we have the Pérez model modified for the first half of the 20th century, following the observations of Tylecote: until 1914 the latest expansion of the cheap steel and electricity (IIIK) paradigm coincides with the installation of the Fordist paradigm; the expansion leads to the crisis of growth represented by the First World War. This crisis is socially and politically severe because there were no radical reforms in the IIIK, but the economic expansion continued for several years. This first expansion of mass production led to the depression of 1930 (extreme decoupling). The depth of the economic, social and political crisis led to radical reforms that gave rise to the known expansive wave: the golden age of capitalism. This period is the final expansion of the IVK that began in 1908; that $\mathrm{K}$ culminates with a short descending wave at the end of the 1960s (the part not captured by the figure). Thus, the rule of regular extension of about 50 years is broken to extend it to little more than seventy years, with two intermediate crises, although with different intensity (op. cit.).

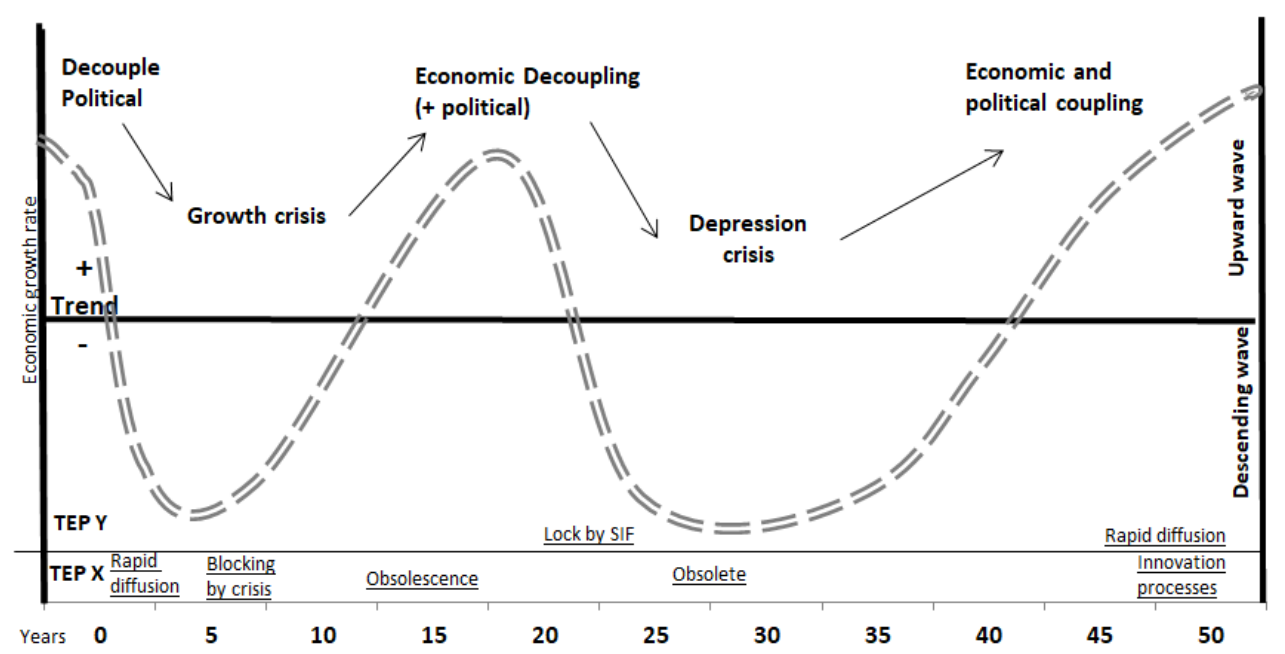

Figure 2 - Perez's growth wave model modified for the first half of the 20th century (Tylecote 1992: 24)

We can draw certain tentative conclusions because the structural changes that affect the accumulation 
of capital and the retro-feeder forces still need to be incorporated into the analysis.

a. In the final expansion of the IVK (from the culmination of World War II), the electronic era began with the invention of the transistor at the end of the 1940s and the beginning of the 1950s. At the end of the IVK (with the double crisis of the early 1970s) installed the VK (with the presentation of the first microprocessor, 4044 INTEL, see Freeman \& Luoca, 2001). As noted, the terminal crisis of the IV K coincides with the installation of the $\mathrm{V}$.

b. In the ascending waves, although the driving force is technology and capital, the wave is shaped by the social struggle and its crystallization in political-institutional structures. Therefore, there tend to be two highs and two losses in an upward wave caused by internal crises that can lengthen or shorten these waves.

Despite the presence of factors of open causality, there is an important pre-determination in the dynamics of long waves, from which we can deduce a heuristic. If a boom is prolonged, like that of the IVK, it is because it was preceded by a deep depression and, therefore, generated the need and possibility of carrying out in-depth reforms (the Benefactor State); it follows that the terminal crisis of the IVK will tend to be brief (as it was in the 1970s), because the strength of the previous reforms still serves as a buffer against the contractionary effects of economic activity.

It should be noted that in the face of an attenuated crisis, as pointed out by Tylecote (op. cit.), the incentive for a profound reform is not present, so the shock wave will tend to be limited in its extension and depth. This is because the way is prepared for an economic depression, which can act as a laboratory to trigger a profound reform, but the result is open, since the reform that takes place may not guarantee the "coupling" between the techno-economic paradigm and the socio-institutional framework. The previous heuristic serves as a basis for the hypothesis, constituting the guiding thread of the exhibition and the eventual corroboration of the central approach, particularly the transition conditions from V to VIK.

Structural changes and feedback factors. Solomou (op. cit.) made the crucial observation that growth waves, whatever their extension and rhythm, are affected by structural changes in the economic system. Everything indicates that one of the most important structural changes began to take shape rapidly in the late nineteenth and early twentieth century, constituting what Kuznets (1973) called "modern economic growth" (propensity for continuous innovation). It is about the growing unification between science, technology and industry. Schumpeter did not grasp the fundamental implications of this process, because he insisted on the autonomous character of science. But as Rosenberg (1976) points out, science tends to endogenize, that is, it is integrated into the dictates of capitalist industrial production. Recall that the advances of physics and electromagnetism were accelerated and led to solid states in the 1940s, but probably its effect was delayed by the hierarchical structure and the growing bureaucratism of the mature mass production (in the golden age).

A second structural change is not in production but in circulation and refers to the emergence of global fiduciary money; that role is assumed by the dollar after the Smithsonian agreements (Graff, Kenwood \& Lougheed, 2015) that involved dissociating it from its metallic base, the troy ounce of gold (see Duncan, 2012). Next, the Basel I and II agreements amplify the banking multiplier by drastically reducing reserve requirements against financial risks (Dumas, op. cit.). This is equivalent to successive discoveries and remittances of gold such as those made by New Spain or the California gold of the 1840s. In turn, the abatement of the real and nominal interest rates derived from the foregoing resulted in pressure to the decrease of the average rate of profit (Dumas, op. cit.); the previous thing collides with counter-tendencies when oligopolistic structures emergent in the most advanced sectors. The latter is probably a third structural change.

Tylecote (op. cit.) emphasizes that feedback factors should also be considered because some of the changes "bounce back" and affect the system as a whole. It is, as this author points out, factors that are affected by growth, but that also affect it, as well as being pro-cyclical or counter-cyclical in nature. In turn, 
the effect on growth can be negative or positive; even the same factor can change sign.

Tylecote lists and analyzes two feedback forces:

a. Money, especially its price, the interest rate. As noted, global fiduciary money drives credit and capital accumulation but becomes a destabilizing force.

b. Population: economic growth affects the population and in turn, the population affects growth. In the VK population growth decreases and the population begins to age, which in the long run slows down the growth rate of productivity.

The hegemonic cycles. Modelski \& Thompson (1996), among other authors, make the observation that there are cycles associated with world leadership, which are amalgamated with the long cycles of capitalism. They propose a succession of world powers that fulfil a specific role in international relations; of the group of capitalist powers, one achieves the leadership and reconfigures the world order based on its hegemony.

The aforementioned author emphasizes that world hegemony goes through three moments: a) harmony, b) delegitimization and c) deconcentration. The first hegemonic power was Portugal from 1516, the second the Netherlands starting in 1609, third Great Britain from 1714 (Modelski, op. cit.); the US began its hegemony in 1914 and reached the phase of delegitimization in 1973 (Modelski \& Thompson, op. cit.). Goldstein points out that an "economic expansion and hegemonic decline" will most likely occur between 2000 and 2030, itself represents a dangerous mix that would express and induce a change in world power (op. cit.: 17).

The profile of the Fifth Kondratiev. With the previous observations we can advance a tentative outline of the VK profile:

a. It was installed in 1971 at the same time that the terminal crisis of Fordism was verified. Taking place a relatively moderate crisis (crisis of growth), the reform that took place is superficial or acts as a counter-reform (neoliberalism) but without limiting the take-off of the VK that began around 1983.

b. To the extent that the expansion that began in 1983 was preceded by superficial reform, there will be a strong tendency for the expansive wave to be comparatively weak in its extension and pace, therefore, as the accumulation of economic and sociopolitical continues, tensions will lead to an economic depression, which began in 2008 .

c. The current economic depression is a period in which two moments are identified: a drastic recession and, after 2010, the depression proper that extends to the present (Roberts, 2016). Although the growth rates of the depressive period are low but positive, what is distinctive is the gap between real growth and the GDP potential of the more advanced countries (see Summers, 2014).

d. Depression could act as an inducer of a fundamental reform, like the one that took place as a result of the depression of the thirties of the previous century. It is a possibility, but not a necessity. Thus the leading country would be further weakened by losing the possibility of a new SIF. In that context, instability and international confrontation would be encouraged.

e. If the economic depression plays a positive role, as was the case in the years 1930-40 with the creation of the Benefactor State, the expansion that follows can be considered an extension of the VK, or can be considered as the installation of a VI. This nominative dilemma has an antecedent when the paradigm of cheap steel and the electric motor was extended and interacted with mass Fordist production, which is considered the axis of the IVK (see Tylecote, op. cit.). We know that conventionally we chose to speak of an IVK since the beginning of the 20th century.

Digitalization and networks as a generic technology. From companies "dot.com" to digital platforms. A generic technology (GT) is a system that due to its broad applicability is susceptible to be used in all branches of production and in human activities in general (see Carlsson, 2004; Helpman \& Trajtenberg, 1998; David, 1990). Carlsson adds that digitalization-networks is superior and its impact is more powerful than previously known GTs such as the steam engine or the electric dynamo. In the above sense, the new 
GT is capable of causing an additional wave of "new combinations", the increase in productivity, efficiency and, ultimately, economic growth.

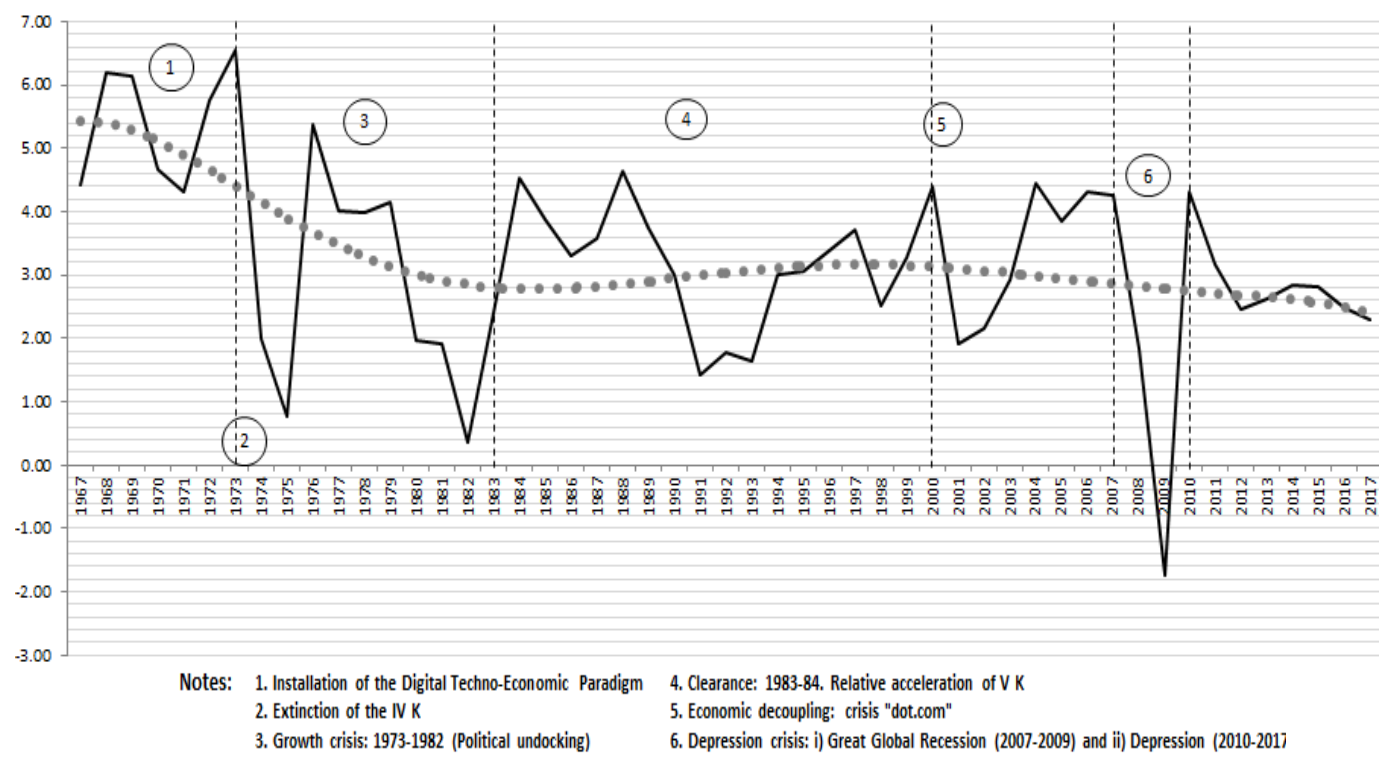

Figure 3 - Global GDP growth rate, 1967 - 2017 (Own elaboration with data from Angus Maddison Project and IMF)

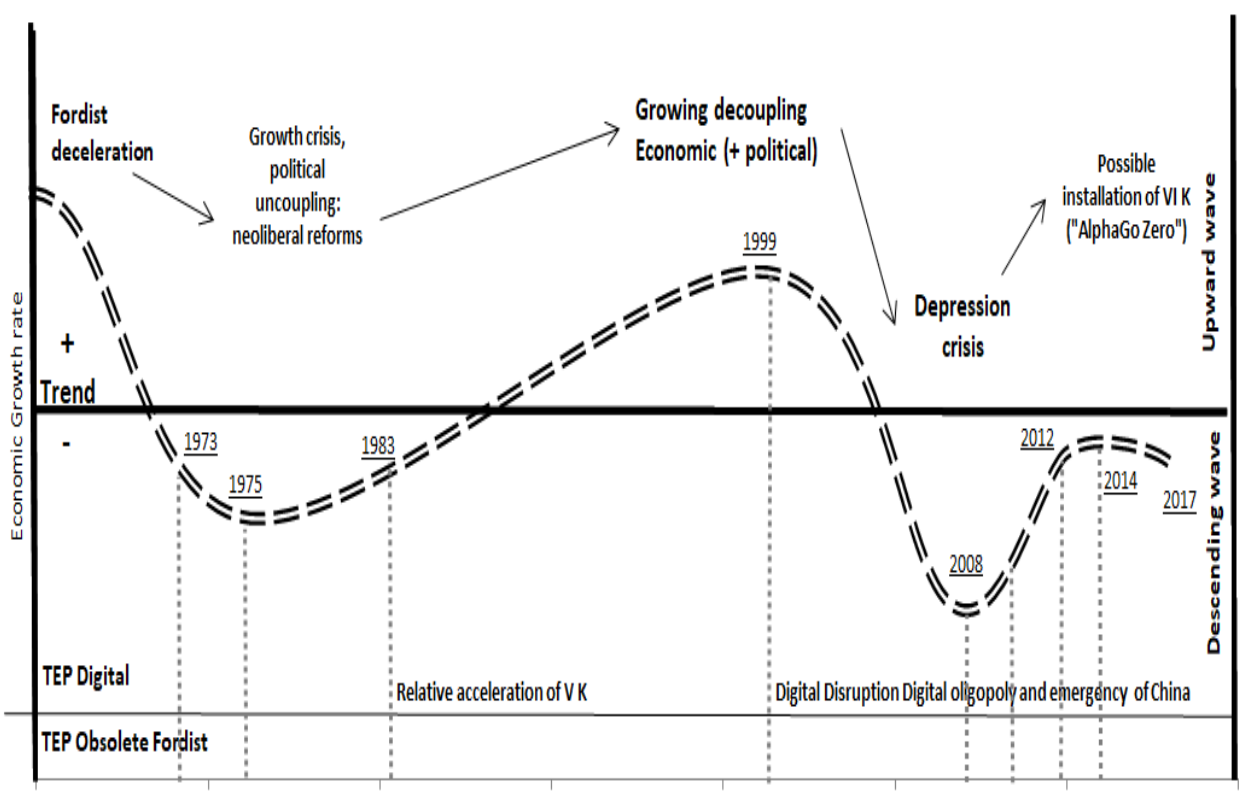

Figure 4 - Perez`s growth wave model modified for XX-XXI century (Own elaboration from Tylecote 1992) 
By circumventing the character of the GT of digitalization, Gordon sees it merely as a technology that is exhausted in data processing (for example, in intensive management activities, such as banking, insurance, airlines, etc.) and in intercommunication (op. cit., see the introduction and chapter 17). Digitalization is, rather, a means to reconfigure the entire productive system, including commerce and finance. As will be explained later on, by breaking down the components of a digital production system, by means of which all known goods can be produced and distributed more efficiently and create entirely new goods and services (digital goods).

For example, the final manufacture of a car will remain attached to the principle of assembling thousands of material components, that doesn't change. The change comes from information flows made up of millions or billions of bits that move at the speed of light. These information flows are governed by the principle of feedback (see Hirschhorn, 1986). In an automatic design and manufacturing system, the bit streams that scan the materials and return feed another device, which interprets the information. In turn, a third device, which may be the extension of the second, enables a mechanical reaction: cutting, abrading, polishing, painting, screwing, etc. (op. cit.). The role of digitalization can go beyond the "production regime", to extend to relations with customers, suppliers, competitors, a principle captured by the concept of e-commerce.

In what we will call the first level of digitalization, the current one, automation is not complete, because it depends on a certain human intervention. The passage to the second level of digitalization, or artificial intelligence, the system works independently of human intervention.

Table 1 - Central features of the advanced fingering system in the 21st century (Own elaboration from Willcocks, 2015; McKinsey, 2013 and 2017a; UNCTAD, 2017)

\begin{tabular}{|l|l|}
\hline \multicolumn{1}{|c|}{ Components } & \multicolumn{1}{c|}{ Expanded functions } \\
\hline a) Sensors & Data analysis systems \\
\hline b) Network Hardware & Cloud Computing \\
\hline c) Computational power & Augmented reality \\
\hline d) Data storage & 3D printing \\
\hline e) Broadband communication & Smallest and most mobile robots \\
\hline
\end{tabular}

From the point of view of the organization, one of the most common is the flexible system of manufacturing: it is a form of automation in which several machines are linked by a system of handling raw materials, parts and components; all aspects of manufacturing are controlled by a central computer (Willcocks, op. cit.). Another form of organization is computer-integrated design and manufacturing (CAD/CAM) that is based on the principle of storing and displaying large amounts of data that represent specifications of parts and products (op. cit.). We will now turn to the social dissemination of digitalizationnetworks as a generic technology.

The crystallization of the generic technology of digitalization. The digital oligopolies. The passage from one technological paradigm to another can be understood as the relay of a generic technology for a superior one (Carlsson, op.cit.). This process of forming a GT can take several decades because the new systems are gradually being perfected and their applications evolve (Rosenberg, 1976). But, above all, users must not only learn to use it and more fundamentally to unravel its principles, potentialities and limitations. This process of adaptation and adoption takes place under adverse cultural conditions, due to the persistence of inertial habituation to the previous systems and processes.

Another problem, perhaps the one that determines the rest, is the regulation or social regulation that is required to achieve a certain balance in the configuration and subsequent technological diffusion, avoiding the formation of monopolistic entities that disproportionately capture the economic benefits of technological change, affecting adversely the diffusion of the new technological paradigm (see theoretical 
framework). Inevitably, the greater the potential of the new system, the regulation will be formulated irregularly, even accidentally. When empty in the regulation some agents that act first (the first movers), not only monopolize the economic rents, but they can define the forms of use and specific design of the new systems, products and services (McKinsey, 2015b \& 2017b; Lanier, 2014).

Computing (in itself another generic technology), software, telecommunications and networks were perfected and converged in the 1990s, giving material support to the World Wide Web (Gordon, op. cit.). In those years the functionality of the GT-digitalization was limited (especially in video), but the accelerated advance in computing power (expressed indirectly in Moore's Law) was going to allow the rapid improvement of the systems (Brynjolfsson \& McAfee, 2014). The telecommunications crisis detonated in 2000 was the culmination of a chaotic process of experimentation, in which the "dot.com" companies quickly flourished and the transatlantic fibre optic cable was laid (see Cassidey, 2002). From this crisis emerged an approach to the dominant design of the digital economy, as well as the project of what Lanier (2014) calls the "monetization of the digital economy". The organizational design was baptized first as "the new economy", being Michael Mandel (1996) one of its apologists. This new economy bore the promise of overcoming the economic cycle, greater power to consumers due to the suppression of intermediation, more computing power at the service of the individual, etc. (Mandel, op. cit.).

The failed business model "dot.com" (Freeman, 2001) gave way to digital platforms (Gawer \& Cusumano, 2013). A digital platform constitutes a network articulated around an axis that can be technological, commercial and social, thus enabling the integration and coordinated action of many agents that gravitate around the axis of the platform, forming an ecosystem and enabling the improvement of the borders between markets (Gawer \& Cusumano, op.cit.).

There are three variants of digital platforms, but none is regulated (Lanier, op. cit.). The first attempt to establish an anti-monopoly action focused on the nexus between the Windows operating system and its Explorer browser and failed (Liebowitz \& Margolis, 2001); this fact expressed the disorientation caused by the unprecedented course of technological change.

The three basic variants of the platform are: a) the e-commerce platforms whose most successful case, Amazon, tends to push the limit of the elimination of commercial intermediation; b) the one that is based on technological innovation, such as INTEL or CISCO and for supposed Windows and; c) the social variant, which specializes in the interconnection of users, in order to accumulate large databases, following the model initially experienced by NAPSTER. Napster was a site of interconnection and free exchange of musical files created in the 1990s, achieving the adhesion of millions of users. In 2001, it was closed by means of a court order on charges of infringing copyrights. Despite the above, the principle of digital socialization proved to be enormously fruifful and is the one that copied Facebook, even appropriating the idea of the foundation by university students who worked modestly in their bedroom.

Digital platforms, often offering seemingly free services, are generating huge economic rents. As explained by Lanier (op. cit.), gratuity and freedom of information were predominantly the result of the activism of the Silicon Valley technologists and resulted in several key postulates of the digital era, not only the open source but the monitoring of the users of the Web.

But for its architecture, digital platforms tend to restrict competition and direct technological progress (Lanier, op. cit.). This ambivalence of technological systems is not new and in the past social controls have been successfully established to limit the negative effects on the labour process, competition and income distribution (in the case of Standard Oil, Glass-Steagall). At present it is not so, not only mainly because of the postulates of the neoliberal doctrine but because of what Lanier (op. cit.) and McKinsey Global Institute $(2015 b)$ calls the principle of "all the benefit to the winner". We will return on that point.

The technology-based platform shares characteristics observed in similar oligopolies of the second industrial revolution, or in the dawn of the current industrial revolution; the consolidation of the leading company implies a relentless race to achieve the superiority of products and processes and to that extent 
ensure control of the market. The difference established by the digital economy is that innovations are interrelated, so the key to achieving market power lies in offering the product or technology that centralizes that relationship and induces the activities of other companies to produce, adopt and/or innovate around the activities of the leading company (Gawer \& Cusumano, op. cit.). Once the leadership is achieved, the platform leader has the power to determine the content and direction of technological change, which amounts to a formidable barrier to entry.

The foregoing is corroborated in the strategy of INTEL, creator of one of the most successful digital platforms. The following is based on Gawer \& Cusumano (op. cit.), unless another source is indicated. For INTEL to become a leader, it had to ensure that there was demand for its processors; that demand would justify the increasing investments in R\&D to produce ever faster and more powerful devices. The problem is that users do not buy microprocessors directly, but computers. The goal of INTEL, therefore, involved changes that went far beyond its own product, since the architecture of the PCs had to improve substantially to use the growing computing power. One of the most important changes in the architecture of the PC promoted by INTEL was the compatible chip, the Pentium, which allowed overcome the fragmentation of the market caused by non-universal designs. INTEL's leadership implied that hardware manufacturers adopted that standard and produced according to the specifications derived from it. Once that standard was reached, the company already controlled the pace and direction of technological change, which led not only to faster and more powerful microprocessors but also to Wintel architecture (a monopoly agreement between Intel and Microsoft).

In the other two variants, e-commerce and the so-called NAPSTER or social networks, the principle and foundation are network externalities, which give it characteristics of natural monopoly in its specific sector, in such a way that first movers block access to the followers. The most disruptive platform is the NAPSTER type because it hides behind a principle that seems socialist (social goods freely and freely shared), a formidable machinery for economic valorization. Facebook's strategy, for example, is to convert data into "capital," as Arrieta et. al. (2017), either by using them on their own account or by reselling them to other users who use it as raw material for machine learning (lbid.).

All platforms are associated with an exponential increase in computing power, which feeds back the domain they exercise; which cascades the new repercussions. It is, as Lanier (op. cit.) explains, an entirely unexpected aspect of the digital revolution. At first, it was thought that the computing power would be distributed evenly among all users (like electric light) and none of the agents would have the ability by this means to dominate others. It has not been, unfortunately, because what Lanier (op. cit.) calls the siren servers are powerful nodes that dominate the network based on a powerful IT infrastructure of servers located in secret places, usually with access to rivers, which serve as coolers and dissipate the heat generated by the supercomputers, performing the function of the so-called cloud (Lanier, op. cit.; Arrieta, et al., op. cit.).

The ability to accumulate data thanks to the growing power of computing leads to big data and analytics changing the dynamics of entire sectors such as insurance and health care in the US. The big data-analytics constituted another denial of the libertarian ideals that characterized the beginning of the digital era (Lanier, op. cit.). Although the grains of sand of individual information are innocuous in themselves, their accumulation confers not only monopoly power in the traditional sense, but the ability to control markets, the behaviour of users and even the perception of reality. The set of polarizing effects caused by the establishment of the digital economy in the US has been dubbed by the McKinsey Global Institute as a digital disruption. MGI generally defines digital disruption as the result of three new processes: dematerialization (converting the physical to virtual), disintermediation (eliminating the intermediary) and disintegration (breaking large items like cars and repackaging them as services). Here the meaning extends to express the idea that those three impacts when occurring in a certain regulatory vacuum, leave most of the companies adrift, since the principle of network externalities preferentially 
favours the first movers. The result is the fracture of the productive apparatus, the increase in inequality and unequal patterns of economic performance, as is experienced in American society (McKinsey, 2015a \& 2015b; Black et. al., 2017). Such digital disruption is at the centre of what we have called the "shortening" of the VK, which has helped to feedback the current picture of inequality and social marginalization. However, as noted, another mode of social instauration of the aforementioned technological system has emerged in the People's Republic of China (PRC); this new modality tends to favour "integration" effects instead of disruptive ones. To consider some implications of this phenomenon, we will compare some of the salient features of both modalities. This exercise will also help to deepen the relationship between the VK and the hegemonic cycle.

Disruption vs. digital integration in the Fifth Kondratiev: United States and the People's Republic of China. Digital supremacy in the midst of social disarticulation in the US. The USA is the leading technological power of the digital age and the hegemonic power of the capitalist world. To what extent does this country face competition from other countries in the digital economy? To answer, we must first differentiate between the adoption of digital tools and systems and the adoption of the digital productive system.

Table 2 - Venture capital invested in digital-based technologies in 2016. Leading countries (millions of dollars) (McKinsey 2017c: 3)

\begin{tabular}{|c|c|c|c|c|c|}
\hline Countries & Fintech & Countries & $\begin{array}{c}\text { Virtual } \\
\text { reality }\end{array}$ & Countries & $\begin{array}{c}\text { Technologic } \\
\text { education }\end{array}$ \\
\hline USA & 5,437 & USA & 1,437 & USA & 582 \\
\hline China & 7,158 & China & 1,312 & China & 357 \\
\hline United Kingdom & 1,793 & Japan & 166 & Japan & 268 \\
\hline Germany & 668 & United Kingdom & 73 & Australia & 264 \\
\hline Japan & 493 & France & 166 & United Kingdom & 142 \\
\hline Countries & Wearables & Countries & $\begin{array}{c}\text { Technologic } \\
\text { education }\end{array}$ & Countries & $\begin{array}{c}\text { Robots and } \\
\text { drones }\end{array}$ \\
\hline USA & 1,724 & USA & 1,282 & USA & 728 \\
\hline China & 992 & China & 681 & China & 227 \\
\hline Germany & 170 & Japan & 217 & Japan & 129 \\
\hline Canada & 134 & United Kingdom & 163 & Singapore & 96 \\
\hline United Kingdom & 95 & India & 145 & Canada & 59 \\
\hline Countries & $3 \mathrm{D}$ printer & Countries & Big data & Countries & $\begin{array}{c}\text { Al and } \\
\text { Autonomou } \\
\text { s Learning }\end{array}$ \\
\hline USA & 602 & USA & 6,065 & USA & 3,728 \\
\hline China & 221 & United Kingdom & 1,673 & United Kingdom & 1,222 \\
\hline Germany & 182 & China & 942 & China & 900 \\
\hline Japan & 181 & Singapore & 651 & Japan & 473 \\
\hline Russia & 181 & Russia & 554 & Australia & 329 \\
\hline
\end{tabular}

This difference can be illustrated by importing automobiles and producing automobiles by copying automotive technology. The European powers, Japan and the Republic of Korea are in the first category, which does not exclude the exploitation of certain digital niches. The PRC is located in the second group, since it is adopting the digital productive system, relying on the advantage of the followers, competing directly with the leader (USA) although, as we will see, with a different socio-institutional orientation. 
To appreciate the difference between producers (leader and follower) and adapters, let's see the following data. From the point of view of the diffusion of e-commerce, whether inter-business (B2B) or companies and consumers (B2C), the Republic of Korea is at the forefront with the equivalent of $84 \%$ of GDP, following Japan with $60 \%$; USA occupies the third place with less than half of the pointer (UNCTAD, 2017). In contrast, from the point of view of value added in information and communication services, the US advantage is notorious: $42 \%$; the EU has a high percentage, but close to half of the United States $(26 \%)$; in Japan it is substantially lower, $8 \%$ and even lower in Korea, $2 \%$ (See UNCTAD, op. cit.).

If we use the investment indicator made in digital technologies by means of risk capital, we see that it is basically a fight between two contenders, USA and the PRC.

American corporations enjoy a supremacy position, taking the majority share of net corporate profits as shown in Table 3. The aforementioned share is $19 \%$ against $6 \%$ of Japanese and little more than German companies. But the PRC, despite being classified as "emerging" or late development, has a greater participation, of $14 \%$.

Table 3 - Net corporate profits by region and country, 2013 (McKinsey 2015b: 3)

\begin{tabular}{|l|l|l|l|}
\hline 1. North America & $26 \%$ & 8. Latin America & $6 \%$ \\
\hline 2. Western Europe & $25 \%$ & 9. Other Developed Economies & $5 \%$ \\
\hline 3. United States* & $19 \%$ & 10. Association of Southeast Asian Nations & $5 \%$ \\
\hline 4. China & $14 \%$ & 11. South Korea & $5 \%$ \\
\hline 5. Germany & $8 \%$ & 12. Australia and New Zealand & $3 \%$ \\
\hline 6. Japan & $7 \%$ & 13. Other Emerging Economies & $2 \%$ \\
\hline 7. Canada & $7 \%$ & 14. India & $1 \%$ \\
\hline
\end{tabular}

Note: * Estimated share according to GDP

Although the US digital monopolies enjoy a colossal profitability, the economy of that country suffers the effects of a social and productive fracture in the centre of which is the aforementioned digital disruption.

The productive fracture in the United States has been widely discussed by several authors (see Stiglitz, 2016; Sachs, 2017). We will focus on two of the most outstanding indicators: a) the decline in the productivity growth rate (already pointed out by Gordon, op. cit.), observable in other developed countries, and $b$ ) the reduction in the percentage of labour participation, which although it is not unique to the United States, it has a more radical aspect in it.

Table 4 - Annual productivity growth rates, 1980-2016 (Own preparation with data from PennWorldTables)

\begin{tabular}{|c|c|c|}
\hline Years & United States & Developed Countries \\
\hline $1980-1990$ & 1.9 & 1.7 \\
\hline $1990-2000$ & 4.1 & 1.8 \\
\hline $2000-2007$ & 2.6 & -1.7 \\
\hline $2007-2014$ & 1.6 & -0.4 \\
\hline
\end{tabular}

Regarding the productivity growth rate, we present Table 4 with data very similar to those presented by Gordon in the aforementioned work. It is noted that the growth rate of productivity in the US rebounded briefly between the mid-1990s and the middle of the next decade, but then declined. In the set of developed countries, the performance is even more unfavourable.

What we will call the paradox of productivity is explained, as it is based on the hypothesis, not from the intrinsic characteristics of digitalization, but by the weakness of the political and socio-institutional 
framework in which this technology is exploited. The decoupling between the technological paradigm and the socio-institutional framework has its axis primarily in the digital disruption, but exacerbates the social disarticulation that preceded the digital era. Let's see the mentioned data. One of the most disturbing manifestations of social regression is the reduction in the labour participation rate, which is higher in men than in women (see Table 5).

Table 5 - Labour participation rate (with age of 15 years or more) \% (Own preparation with data from Data. World Bank)

\begin{tabular}{|c|c|c|c|c|}
\hline \multirow{2}{*}{ Year } & \multicolumn{3}{|c|}{ United States } & World \\
\cline { 2 - 5 } & Total & Man & Woman & Total \\
\hline 1990 & 66.5 & 76.4 & 57.5 & 80.0 \\
\hline 1995 & 66.8 & 74.9 & 59.3 & 79.3 \\
\hline 2000 & 67.1 & 74.8 & 59.9 & 78.4 \\
\hline 2005 & 66.0 & 73.3 & 59.3 & 77.4 \\
\hline 2010 & 64.7 & 71.2 & 58.6 & 76.2 \\
\hline 2015 & 62.6 & 69.0 & 56.7 & 75.5 \\
\hline 2016 & 62.8 & 69.2 & 56.8 & 75.3 \\
\hline
\end{tabular}

In this regard a study by Black, et. al. (op. cit.) notes that the labor participation rate of men aged between 25 and 54 has been declining in the USA for more than 60 years, but it has fallen more rapidly since 2000 in that country than any other OECD (except one). The aforementioned study adds that the most affected workers are the least skilled. Again in the USA the negative impact on that category of workers has been stronger than in the rest of the OECD, which suggests that what has failed is the institutional support to requalify the workers.

On the supply side we know that the birth rate has been decreasing and at the same time there has been a gap in the qualification levels of the workers (Gordon, 2014). On the demand side, companies due to technological reasons (technological disqualification) and due to globalization (replaced by lower-wage workers) hire fewer Americans from the aforementioned labour category (IMF, 2017). As for the institutional, Black et. al., highlights that the USA has the lowest level of labour regulation, the lowest degree of protection and collective bargaining that any of its counterparts. In particular, the US government spends relatively less on re-training, subsidies for childcare and support for dismissal (op. cit.).

To the previous data, it can be added that the form that has adopted the digitization contributed to the gap between the potential growth rate of GDP and the respective real growth rate in the US (see data in Summers, op.cit.). Significantly, this gap widens in the take-off period of the digital age.

Digital disruption in the US according to McKinsey Global Institute is expressed in the following main processes:

a. Due to network externalities, digitization has spread very unequally, concentrating, as we will see, on one pole (information technology, multimedia, professional services and partially finance and insurance sector, see Table 6) and leaving behind most of the industrial and service companies.

b. The first movers (that is, those who have grasped the new common sense of digital profitability) have advantages of scale, network effects and positioning raise barriers to entry. The process of exclusion is more radical due to the effect of digital platforms. The digital platform allows the leading company to cross sectoral boundaries and sucks economic rents from a large part of the economy.

c. Digitalization, while is creating new economic value, is destroying at the same time other sources of profitability at an equally accelerated rate. Traditional companies have lost $40 \%$ of their revenue growth 
and $25 \%$ of their profits because of competition, as they are forced to accept price cuts or invest more defensively.

d. The modification in the supply-demand structure has led to the disappearance of links in the productive and commercial chain and at the same time it has converted various services into obsolete ones (for $3 / 4$ of the firms the growth of digital earnings has been negative, but increase for the upper quartile).

e. The winners, by virtue of the superiority that confers them the digitalization, accumulate enormous amounts of data, which turn into another source of profit.

f. Although the users of the services based on digitalization have access to many of them apparently free of charge, as workers are mostly on the losing side. Digital algorithms drastically reduce the employment coefficient and devalue pre-digital skills and knowledge. This has contributed to the aforementioned reduction in the labour participation coefficient in the United States and in the world (see Table 5). This fact has also contributed to the much-discussed decrease in the share of wages in national income, a phenomenon characteristic of the current phase.

Taken together, these effects have caused a breakdown in US industry, as indicated in the data shown in Table 6, the majority of the firms are insufficiently digitized and therefore have a lower performance and suffer the repercussions caused by leading companies (destruction of economic rents, marginalization of new markets, lower average salaries, etc.).

As can clearly be seen, the productive branches that are on the technological frontier of digitalization are basically the four mentioned. A digital gap has been created between the leaders and the rest of the industry that covers the activities of production, marketing, finance and job training. Note that basic manufacturing, mining, transport and storage are lagging behind just as the agricultural sector. In intermediate conditions are: wholesale trade, advanced manufactures, oil and gas and other services. While health, hospital and construction services carry the greatest backlog, especially with regard to training and digitalization of work. The lag in training and digitalization of work is crucial to explain the wage gap and more generally the picture of social inequality that affects developed countries, mainly the United States (see Piketty, 2014).

Digitalization as a way to integrate the economy and global leadership: the case of the PRC. Until relatively recently the idea was emphasized that the PRC had become an industrial power, achieved a global competitive position basically as a technological imitator, two decades behind the technological frontier and under the relentless logic of the Red Queen (see Breznitz \& Murphree, 2011). However, almost surprisingly, in the course of less than a decade that country began to build the foundations of its digital economy, until now becoming the second global power. Such an achievement required integrating a variety of factors to achieve that goal in record time. A decisive step was the founding of Xiaomi, a domestic supplier of smartphones of good quality and low price, available to hundreds of millions of Chinese people, until reaching an inter-connectivity of nearly 800 million inhabitants (Financial Times, November 11 of 2014). An advantage in favour of China is its status as a follower, since it can learn from the leader by achieving huge savings in investment of resources and time; the above explains the decision to adopt the US organizational model. Alibaba Group is inspired by Amazon; Baidu, as a search engine, is organized under lines similar to Google; and Tencent, by focusing on online multimedia, is based on Facebook.

But it should not be overlooked that both national modalities are opposed in two fundamental aspects: in the USA the deregulation prevails and therefore the principle of "the winner takes everything", the axis of social inequality in that country; in the PRC instead, although there are free market principles, since the digital giants are privately owned, the strategic guidelines are formulated in the highest spheres of state power (the State Council and the Politburo); at the same time, they operate strategic design mechanisms to disseminate socially the digital tools, in order to overcome the lags and inefficiency in various sectors of the economy (CAICT, 2017). 
Table 6 - Digitization index of the American industry (McKinsey Global Institute 2015a: 5)

\begin{tabular}{|c|c|c|c|c|c|c|c|c|c|c|c|c|c|}
\hline \multirow[b]{2}{*}{ SECTOR } & \multirow[b]{2}{*}{ 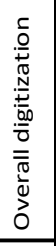 } & \multicolumn{2}{|c|}{ ASSETS } & \multicolumn{4}{|c|}{ USE } & \multicolumn{3}{|c|}{ LABOR } & \multirow[b]{2}{*}{$\begin{array}{l}\widehat{0} \\
\frac{0}{0} \\
\frac{1}{\pi} \\
\frac{5}{n} \\
0 \\
0 \\
0\end{array}$} & \multirow[b]{2}{*}{ 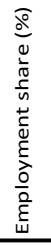 } & \multirow[b]{2}{*}{ 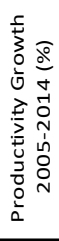 } \\
\hline & & 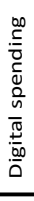 & 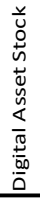 & 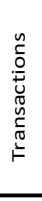 & 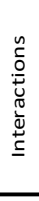 & 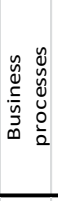 & 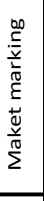 & 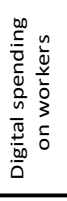 & 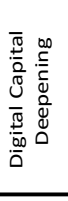 & 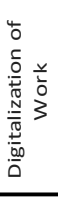 & & & \\
\hline ICT & 6 & 6 & 6 & 5 & 5 & 5 & 5 & 6 & 6 & 6 & 5 & 3 & 4.6 \\
\hline Media & 5 & 5 & 5 & 5 & 5 & 5 & 5 & 5 & 5 & 5 & 2 & 1 & 3.6 \\
\hline Professional services & 5 & 5 & 5 & 2 & 5 & 5 & 5 & 5 & 5 & 5 & 9 & 6 & 0.3 \\
\hline Finance and insurance & 5 & 4 & 4 & 5 & 4 & 4 & 5 & 4 & 5 & 5 & 8 & 4 & 1.6 \\
\hline Wholesale trade & 4 & 4 & 5 & 3 & 3 & 3 & 3 & 3 & 4 & 4 & 5 & 4 & 0.2 \\
\hline Advanced manugacturing & 4 & 3 & 4 & 3 & 3 & 5 & 4 & 4 & 3 & 4 & 3 & 2 & 2.6 \\
\hline Oil and gas & 4 & 2 & 1 & 4 & 1 & 3 & 1 & 5 & 4 & 4 & 2 & 0.1 & 2.9 \\
\hline Utilities & 4 & 2 & 2 & 4 & 3 & 4 & 4 & 4 & 5 & 4 & 2 & 0.4 & 1.3 \\
\hline Chemicals and pharmaceuticals & 2 & 1 & 3 & 4 & 3 & 4 & 1 & 3 & 4 & 3 & 2 & 1 & 1.8 \\
\hline Basic goods manufacturing & 2 & 1 & 3 & 3 & 2 & 4 & 4 & 3 & 2 & 2 & 5 & 5 & 1.2 \\
\hline Mining & 1 & 1 & 3 & 4 & 1 & 2 & 1 & 2 & 3 & 1 & 1 & 0.4 & 0.5 \\
\hline Real estate & $3^{* *}$ & 3 & 1 & 5 & 1 & 2 & 5 & 5 & 3 & 3 & 5 & 1 & 2.3 \\
\hline Transportation and warehousing & $2 * *$ & 2 & 3 & 3 & 5 & 3 & 3 & 2 & 2 & 2 & 3 & 3 & 1.4 \\
\hline Education & $3 * *$ & 4 & 2 & 2 & 4 & 1 & 1 & 3 & 3 & 3 & 2 & 2 & -0.5 \\
\hline Retail trade & $3 * *$ & 4 & 4 & 2 & 4 & 5 & 5 & 2 & 2 & 1 & 5 & 11 & -1.1 \\
\hline Entertainment and recreation & 1 & 3 & 1 & 1 & 3 & 3 & 3 & 1 & 1 & 1 & 1 & 1 & 0.9 \\
\hline Personal and local services & 3 & 5 & 4 & 2 & 5 & 2 & 5 & 2 & 2 & 3 & 6 & 11 & 0.5 \\
\hline Government & $3^{* *}$ & 3 & 3 & 2 & 2 & 1 & 3 & 3 & 4 & 3 & 16 & 15 & 0.2 \\
\hline Health care & 2 & 3 & 2 & 1 & 3 & 2 & 3 & 1 & 1 & 2 & 10 & 13 & -0.1 \\
\hline Hospitality & $1^{* *}$ & 2 & 1 & 1 & 4 & 2 & 4 & 1 & 1 & 1 & 4 & 8 & -0.9 \\
\hline Construction & 1 & 1 & 2 & 1 & 1 & 1 & 2 & 1 & 1 & 2 & 3 & 5 & -1.4 \\
\hline Agriculture and hunting & 1 & 1 & 1 & 1 & 1 & 1 & 1 & 1 & 1 & 1 & 1 & 1 & -0.9 \\
\hline
\end{tabular}

Notes: 1 = Low digitization ... 6 = High digitization.

** = Digital leaders within relatively non-digital sectors.

The importance of strategic guidelines in the development of the digital economy, especially certain hard provisions (such as market reserve and absolute preference for national companies) have caused controversy over whether the PRC abandoned free market economic reform and a return to the "command" economy is being verified (US Chamber of Commerce, 2017). The bewilderment was fuelled by the resolutions of the Third Plenary at the end of 2013 in favour of market reform and financial liberalization (see The Economist, November 2, 2013). Some authors such as Ernst $(2013,2014)$ argue that the goal of achieving technological independence in semiconductors (the basis of digital development), formulated officially in 2014 , is unattainable within the framework of the restrictions that have supported the rise of Chinese digital giants. In contrast, Chen and Naugthon (2016) argue that unlike Japan and the Republic of Korea, which abandoned industrial policy in favor of the free market as they approached the technological frontier, the PRC broke with the trajectory of 2003 liberal, in favour of a strategy that they call techno-industrial.

The publication of the strategic plan Made in China $2025(\mathrm{HC})$ corroborates the point made by Chen \& Naugthon (op. cit.). $\mathrm{HC}$ intends to turn this country, under the direction of the state, into a global industrial leader, focusing on 10 strategic industries, starting with information and communication technologies 
(Council of State, 2015). The axes of this master strategy (preferential access to national companies, subsidized and targeted financing, endogenizing R\&D, replacing foreign technology at the time) have been applied extensively to turn China into a global digital power.

The advance of the digitalization in the PRC, as the aforementioned McKinsey study says, has reached high levels and its potential is enormous, but it is not captured by conventional indexes such as those published by the World Bank, which places it at 50 of 118. The essence of the Chinese model lies in turning digitalization into the main driving force of its economy, based on four factors:

a. The conversion of the BAT group (Baidu, Alibaba and Tencent) at the spearhead to open the way to the next waves of digital companies.

b. A vast market of users who have access to the foundations of the digital economy, such as highspeed internet and quality mobile communication devices, accessible to the broadest segments of the population.

c. The flexible action of the state as promoter and facilitator, which encourages innovation and offers capital, all under a form of interventionism that equilibrates the balance between suppliers and users. The axis is to concentrate the investment in digitalization, especially as venture capital, the most suitable in the promotion of intangible assets.

d. Use digitalization as a factor to accelerate productivity to close the gap with the leading powers.

A first objective is to universalize, based on the high diffusion of the internet, what we will call basic services such as e-commerce and digital payments. According to the MGI (2017c) the value of transactions by e-commerce are greater than those made by France, Germany, Japan, United Kingdom and USA. In digital payments among Internet users the percentage raised from $25 \%$ in 2013 to $68 \%$ in 2016 of the total population.

The second objective is to redesign the ecosystems that form within digital platforms, supported by big data, analytics, robotics and $\mathrm{Al}$, encouraging the promotion and active incorporation of start-ups and incentives for traditional companies to adopt the tools digital (McKinsey, op. cit.; Financial Times, October 13, 2017). The first Chinese movers have made fabulous profits, but the rule of the game, as noted, is that they become active re-investors to promote the development of new digital capabilities and their diffusion to the rest of the economy. According to McKinsey (op. cit.), the venture capital industry in China, focused on the digital economy, is the most dynamic in the world, going from 6\% of the global total in 2011-2013 to $19 \%$ in $2014-2016$.

In the social sense, perhaps the most significant in the transformation of basic services such as health care, which is being digitized, not with the primary goal of amassing enormous private fortunes, but to raise the quality of services and their coverage (see CMH, 2012; McKinsey, op. cit.). This means a radical difference with respect to the US experience, where medical insurance companies actively use big data to exclude users that exceed a certain level of risk (Lanier, op. cit.). McKinsey Global Institute (op. cit.) and the Financial Times (which dedicate a series of publications in this regard) recognize that in a few years the PRC will define the digital technological frontier. In the immediate future, the dynamics of the Chinese digital economy already have a global impact and have an effect on countries, industries and communities, partially offsetting the dependence on foreign technology, mainly from the US.

As can be seen from above and from the information in Table 2, technological competence has focused on USA and China (Lucas \& Waters 2018), because both seek leadership in the next expansive wave based on digitalization, that is, robotics and artificial intelligence (based in turn on the extension of the VK or a VIK). To the extent that this confrontation between the leader and the follower also means the competition of two socio-institutional models of using digital technology, its outcome can determine the global future in a very broad sense. However, in the opinion of various political observers, a long conflict has arisen in which periods of commercial confrontation alternate with periods of negotiation, until reaching a climax where the two superpowers would measure forces in a definitive manner. As has happened in 
previous historical periods, this final confrontation is part of the transformation of the world power system and thus will redefine the dynamics of the next Kondratiev. As Goldstein (op. cit.) points out for the coming decades, the world order should be built not on the confrontation of powers, but on the basis of mutual security.

In conclusion. In order to understand the dynamics of the world capitalist economy, particularly in recent decades, the long-wave approach called Kondratiev is indispensable. Making key modifications to this theoretical statute and applying it to the period of expansion that takes place between the beginning of the 1980s and the outbreak of the global financial crisis, it is possible to capture the specificity of the ascending VK. The deployment of powerful information and communication technology should have propelled productivity and economic growth. The previous thing only happened limitedly and the VK was "shortened". Given the need to find an alternative explanation, some authors point out that digital and network technology, the axis of ICT, has a limited capacity to influence the fundamental forces of growth. Against this explanation, it was argued here that the leading country and global hegemonic power, the United States, was caught in a severe digital disruption that, in addition to affecting average productivity, has generated processes of economic concentration and social polarization, synthesized in the phrase: the winner takes everything.

The deregulation and the absence of counterweights characteristic of US institutions explain the conversion of powerful digital technology into a disruptive factor instead of an integrating factor. The other world powers, with the exception of the PRC, have become just users of digital products and services generated by USA. Only China has ventured, and successfully, to become a digital producer, competing directly with American monopolies. But to the extent that this competition is not primarily about trade and market in the conventional sense, but a clash of normative models of social exploitation of the digitalization, we are properly before a struggle for world hegemony.

The above means that the dynamics of the VK, being in its stage of economic depression, will be determined by the tensions derived from the transition of the hegemonic cycle. In the case of an unstable period, two main scenarios are prefigured: one based on commitment along with international reforms and the other on direct (though not necessarily military) confrontation. It is to be hoped that after the painful lessons left by the hegemonic wars that have occurred since the sixteenth century, the logic of the accumulation of power has finally been broken.

Arrieta, I., Goff, L., Jiménez, D., Lainier, J., Weyl, G. E. (2017). "Should We Treat Data as Labor? Moving From 'Free ".'American Economic Association. Papers \&Proceedings.5.

Bell, Daniel, (2015). The China Model. Political Meritocracy and the Limits of Democracy, Princeton: Princeton University Press. Black; Sandra, J. Furman, E. Rackstraw y N. Rao.(2017). "The Long Term Decline in US Prime-Age Labour Force Participation", VOX CEPR's Portal, 4 de mayo.

Brybjolfsson, E. y Mcafee, A. (2014).The Second Machine Age: Work, Progress, and Prosperity in a Time of Brilliant Technologies.New York: W W Norton \& Co Inc.

Breznitz, D. y Murphree, M. (2011).Run of the Red Queen: Government, Innovation, Globalization, and Economic Growth in China.Yale University Press. 264

Carlsson, B. (2004). The Digital Economy: what is new and what is not?, Structural Change and Economic Dynamics, pp. 245-

Casiddy, John (2002). DotCom: The Greatest Story Ever Sold, PerfectBound, Chanhassen.

Chen, L. y Naughton, B. (2016).An institutionalized policy-making mechanism: China's return to techno-industrial policy.Research Policy,45(10), pp. 2138-2152.

China Academy of Information and Communications Technology (2017). White Paperon Digital EconomyDevelopment, Julio.

David, P.A. (1990). The Dynamo and the Computer: An Historical Perspective on the Modern Productivity Paradox. American Economic Review, 80 (2), Mayo, pp. 355-361.

Dicken, P. (2015). Global Shift.Mapping the Changing Contours of the World Economy.Nueva York: The Guilford Press.

Dumas, C. (2010). Globalisation Fractures. How major nations' interests are now in conflict. London: Profile Books.

Duncan, R. (2012). The New Depression. The Breakdown of the Paper Money Economy.Singapur: John Wiley \& Son.

Ernst, Dieter (2013) Dieter Ernst, "Why does China Still Ply a Limited Role in Semiconductor Innovation, 24 de Julio de 2013, 
Honolulu: East West, Honolulu Center.

Ernst, Dieter (2014). From Catching Up to Forging Ahead? Chinas's Prospects in Semiconductors, Innovation and Economic Growth Series, Núm. 1, noviembre.

Financial Times. (2017). China Next Generation Artificial Intelligence Development Plan, 13 de octubre.

Financial Times. (2018). The AI Race: China and US Compete to Dominate Big Data, 1 de mayo

Freeman, C. (2001). A Hard Landing for the 'New Economy'? Information Technology and the United States National System of Innovation.StructuralChange and Economic Dynamics, 12(2), Julio, pp. 115-139.

Freeman, C., y Louca, F. (2001). El Tiempo pasa: Desde la revolución industrial a la revolución de la información. Oxford: Oxford University Press.

Freeman, C., y Pérez, C. (1988). Structural crises of Adjustment, Business Cycles and Investment Behavior, Technical Change and Economic Theory. pp. 38-66.

Gawer, A. y Cusumano, M. (2013). Industrial Platforms and Ecosystem Innovation.The Journal of Product Innovation Management, pp. 417-433.

Goldstein, J. (1988). Long Cycles.Prosperity and War in the Modern Age. Ann Harbor: Yale University Press.

Gordon, R. (2016). The Rise and Fall of American Growth. Nueva Jersey: Princeton University Press.

- (2014). The Turtle's Progress: Secular Stagnation Meets the Headwinds. En C. Teulings, \& R. Baldwin (eds.), Secular Stagnation: Facts, Causes and Cures. Londres: Centre for Economic Policy Research Press.

Helpman, E., y Trajtenberg, M. (1998). The Diffusion of General Purpose Technologies.En Helpman, E. (Ed.), General Purpose

Technologies and Economic Growth.Cambridge: MIT Press, pp. 85-119.

Hirschhorn, L. (1986). Beyond Mechanization, Cambridge: The MIT Press.

Kondartieff, N.D. (1979 [1925]). Los ciclos económicos largos,Madrid: Akal.

Kondratiev, N. D. (2008 [1928]). Los ciclos largos de la coyuntura económica Trad. por Luis Sandoval Ramírez. México: UNAM-

IIEc-Del Lirio, 2a edición.

Krugman, P. (2012).Detengamos esta crisis ya, México: Editorial Crítica.

Kuznets, S. (1973). Crecimiento económico moderno.Madrid: Aguilar.

Kuznets, S. (1996). "Schumpeter's Business Cycles", en C. Freeman (ed.), Long Waves Theory, Cheltenham: An Elgar

Reference Collection.

Lanier, J. (2014). ¿Quién controla el futuro?, Madrid: Debate.

Liebowitz, S., yMargolis, S. (2001). Winners, Losers \& Microsoft; Competition and Antitrust in High Technology, Oakland IndependentInstitute.

Mandel, E. (1986). Las ondas largas del desarrollo capitalista. La interpretación marxista.Madrid: Siglo XXI.

McKinsey Global Institute (2013). Disruptive technologies: Advances that Will Transform Life, Business, and the Global Economy,Mayo.

- (2015a). Digital America: A Tale of the Haves and Haves Mores. Diciembre.

- (2015b).Playing to Win.The New Global Competition for Corporate Profits, Septiembre.

- (2017a).A Future That Work: Automation, Employment, and Productivity, enero.

- (2017b), The Great Re-Make: Manufacturing for Modern Times, junio.

- (2017c).China's digital economy: a leading global force, agosto.

- Marx, Carlos (1946), El Capital, México: Fondo de Cultura Económica.

Mensch, G. (1979). Stalemate in Technology: Innovations Overcome the Depression. Cambridge: Mass.

Modelski, G. (1987). The Study of Long Cycles.En G. Modelski, Exploring Long Cycles. Londres: Frances Pinter.

Modelski, G.y Thompson, W. (1996). Leading Sectors and World Powers: the Coevolution of Global Economics and Politics, Columbia: University of South Carolina Press.

Piketty, T. (2014). El capital en el siglo XXI, México: Fondo de Cultura Económica.

People Republic of China. State Council. (2015). Made in China 2025, 7 de Julio.

Roberts, M. (2016). La larga depresión. Cómo ocurrió, por qué ocurrió y qué ocurrirá a continuación.Madrid: El Viejo Topo.

Rosenberg, N. (1976). Perspectives on Technology. Cambridge: Cambridge University Press.

Rosenberg, N., Frischtak, C. (1996). Long Waves and Economic Growth: A Critical Appraisal. A.E.R., pp. 146-151.

Sachs, D. J. (2017). Building the New American Economy.Nueva York: Columbia University Press.

Schumpeter, J. ([1939] 2012). Teoría del desenvolvimiento económico: una investigación sobre ganancias, capital, crédito, interés y ciclo económico. México: Fondo de Cultura Económica, $2^{\mathrm{a}}$ edición.

Solomou, S. (1988). Phases of EconomicGrowth, 1850-1973. New York: Cambridge University Press.

Stiglitz, J. (2016). Re-Writing the Rules of the American Economy.New York: W. W. Norton \& Co.

Summers, L. (2014). Reflections on the 'New Secular Stagnation Hypothesis', en C. Teulings, \& R. Baldwin (eds.),Secular

Stagnation: Facts, Causes and Cures (págs. 27-38). Londres: Centre forEconomicPolicyResearchPress.

The Economist. (2013). "Changing the Economy. The Long Week", 3 de noviembre.

Trotsky, L. (1979 [1923]). La curva del desarrollo capitalista.En Los ciclos económicos largos, O.C. Madrid: Akal.

Tylecote, A. (1992). The Long Wave in the World Economy: The Present Crisis in Historical Perspective. Londres: Routledge.

UNCTAD (2017). Informe sobre la Economía de la Información. Digitalización, comercio y desarrollo. Nueva York y Génova: 
Naciones Unidas.

US Chamber of Commerce (2017). Made in China 2025. Global Ambitions on Local Protections, Washington, D. C.

Van Gelderen (1996). Springtide: Reflections on Industrial Development and Price Movements. En Christopher Freeman (ed.). Long Wave Theory, Cheltenham: An Elgar Reference Collection.

Willcocks, L. (2015). Robotic Process Automation at X Changing. The Outsourcing Unit Working Research Paper Serie, 15/03. Londres: Department of Management, The London School of Economics and Political Science.

M. А. Ривера Pioc, д.е.н., професор, Національний автономний університет Мексики (Мехіко, Мексика);

Х. Б. Л. Лопес, аспірант, Національний автономний університет Мексики (Мехіко, Мексика);

Ж. Г. Вейеа, професор, Національний автономний університет Мексики (Мехіко, Мексика).

П'ятий глобальний цикл Кондратьєва: економічна рецесія, нестабільність та монополізація в цифрову епоху

Світова академічна спільнота є єдиною у думці, що динаміка глобальної економіки найбільш реалістично описується концепцією довгих хвиль Кондратьєва. Глобальна експансія світової економіки (так званий період «розширення» - 3 1980-х років до початку світової фінансово-економічної кризи в 2008 році), поштовхом до якої став розвиток інфоормаційних технологій, нанотехнологій, генної інженерії, штучного інтелекту тощо, вважається зростаючою фазою циклу Кондратьєва. Імпульс початку зростаючої хвилі глобального циклу Конратьєва дали Сполучені Штати Америки як лідер розвитку індрормаційних технологій. Відповідно до концепції Кондратьєва, розгортання потужних інформаційнокомунікаційних технологій повинно стимулювати продуктивність та економічне зростання. В той же час, та хвиля, розгортання якої ми спостерігаємо в теперішній час, має обмеження амплітуди та ритму, що призводить до передчасного зниження продуктивності праиі. 3 огляду на потребу знайти адекватне пояснення такого феномену, деякі автори вказують на те, що слабкість п'ятої хвилі глобального циклу Кондратьєва пов'язана не з проблемою технологічного виснаження, а з нестійкою соціально-політичною ситуацією в Сполучених Штатах Америки, що спричинило процеси економічної концентрації та соціальної поляризації. Інші країни, у тому числі і світові лідери, за незначними винятками, стали лише користувачами цифррових продуктів та послуг, що створюються Сполученими Штатами Америки. Тому недосконалість інституційних обмежень такої значної концентрації економічних вигід в одній країні створює суттєві загрози для розвитку світової економіки, дефоормує економічний та соціальний профріль світової спільноти, що у підсумку може трансфрормувати традииійний перебі之 циклу Кондратьєва. Тільки Китай ризикнув і успішно став иифровим виробником, конкуруючи безпосередньо з американськими монополіями. Автор проводить порівняльний аналіз тендениій розвитку економік Сполучених Штатів Америки та Китайської Народної Республіки, розвиток цифррової галузі якої дозволие ій зміцнити свої конкурентні позиції на світовому ринку, порушивши панівне становище Сполучених Штатів Америки. Конкуренція цих двох країн $є$ не тільки фрінансово-економічною, але й політично-інституціональною, що в свою чергу визначатиме характер п'ятого глобального циклу Кондратьєва. Ця конкуренція двох країн-лідерів цифррового простору стосується не стільки торговельних та ринкових переваг в загальноприйнятому значенні, а й означає зіткнення двох глобальних моделей соціальної експлуатації інформаційного середовища, а відповідно - $і$ боротьбу за світову гегемонію. За прогнозами авторів статmі, необхідно розелядати наступні два сценарії розвитку подій: 1) бажаний - введення жорстких обмежень у міжнародне законодавство, що регулює економічні відносини в цисррову епоху; 2) не бажаний - перетворення иифрових технологій з інтеграційного чинника на деструктивний, виникнення прямого (не обов'язково військового) протистояння економік Сполучених Штатів Америки та Китаю.

Ключові слова: інвестиції, венчурний капітал, валовий внутрішній продукт, прибуток, продуктивність, індекс оцифрування 